Island Studies Journal, Vol. 2, No. 1, 2007, pp. 3-26

\title{
Island Archaeology: In Search of a New Horizon
}

Arie Boomert

$\&$

Alistair J. Bright

Faculty of Archaeology, Leiden University

Leiden, The Netherlands

aboomert@hotmail.com

a.j.bright@arch.leidenuniv.nl

\begin{abstract}
This paper charts the academic development of "island archaeology" from its roots in Darwinist and anthropological island studies through island biogeography to processual and post-processual archaeology. It is argued that the rarely made explicit yet fundamental premise of island archaeology that insular human societies show intrinsic characteristics essentially dissimilar from those on mainlands is false. The persistence of this misconception is due in part to the emphasis on islands as ideal units of analysis. It is suggested that island societies should be studied at the level of the archipelago and/or mainland coastal setting within their maritime cultural framework, ultimately leading up to an archaeology of maritime identity.
\end{abstract}

Keywords: Caribbean, insularity, island archaeology, maritime identity, Mediterranean, Oceania

Copyright (C) 2007. Institute of Island Studies, University of Prince Edward Island, Canada.

\section{Introduction}

Over the past few decades a plethora of publications has appeared discussing aspects of what is taken by their authors to be an anthropological (sub)discipline called "island archaeology". Researchers examining the conceptual framework of this field of archaeological investigation have drawn case studies from three of the world's major archipelagoes in particular: Oceania, the Caribbean, and the Mediterranean. While many scholars apparently consider the manifestations of insular societies as essentially different from those in non-island settings, few make explicit the assumptions underlying their belief that island archaeology is a viable domain of study and not merely an application of archaeology to islands. Similarly, the editors of the recently inaugurated Journal of Island and Coastal Archaeology appear to ignore the difference between both viewpoints entirely by simply equating them (Erlandson \& Fitzpatrick, 2006; Fitzpatrick \& Erlandson, 2006).

This paper analyses the developmental background of island archaeology and its research goals as formulated by its proponents. The organizers of a recent conference on the subject address the matter quite transparently by stating that islands show "great variability in material resources, in the life forms and human societies they nurtured and developed 


\section{A. Boomert \& A.J. Bright}

throughout time", but nevertheless "share common, unwritten, almost irrevocable natural laws which control and shape their destinies". These are considered to be "often quite different from mainland situations" (Waldren et al., 2002). The editor of another recent compilation of congress papers on island archaeology states that islands "are deserving of study because in some ways they are in fact biologically and geographically isolated, bounded, and unique". He lists issues of colonization, migration, landscape and ecosystem transformation, demographic change, environmental stressors, and interregional interaction among the variables "that make islands interesting places to study and that are archaeologically distinctive", and adds that one of the main research goals of island archaeology "is determining the extent to which island societies evolved culturally, politically, and economically over time" (Fitzpatrick, 2004a; 2004b).

Clearly, all of this presupposes that there are convincing structural similarities in crosscultural human behaviour restricted to island societies across the world, irrespective of the geographical, climatic, vegetational or other ecological characteristics of the individual insular environments in question. Or, if not that, at least past and present human societies on islands are assumed to show intrinsic characteristics essentially dissimilar from those on mainlands. The question discussed here is whether or not this assumption is supported by any conclusive archaeological and anthropological evidence.

\section{Approaches to Insularity}

What constitutes an island? Land masses surrounded by water may be called "true islands", but biogeographers also distinguish "habitat islands": isolated patches of terrestrial habitat surrounded by completely different habitats other than water, such as mountain tops, caves or oases (Whittaker, 1998:7). True islands are highly variable in physical appearance, ranging from "matchbox continents" such as Madagascar and Greenland (Held, 1989) and relatively large continental (land-bridge) islands like Tasmania to the innumerable tiny isles which dot the world's oceans. Despite not being at all representative of every island category, oceanic islands especially have served as 'island' models to anthropologists and archaeologists. This is illustrative of a lack of rigour that characterizes theoretical and methodological thinking on insular environments as units of archaeological analysis.

Islands evoke strong and uniform images in the Western mind. As any dictionary will testify, insularity as metaphor stands for (physical) isolation, solitude, containment, boundedness and closure, all traceable to a perception of islands as strictly circumscribed units. This notion is enhanced by the tendency to think strictly in terms of oceanic isles when imagining the island model. Also, islands are today often taken as symbols of (social) remoteness and exoticism; they are seen as socio-economically and politically quintessentially peripheral and their inhabitants considered irredeemably provincial (Royle, 2001:22). Islands as archetypical remote enclaves are seen as less tainted by the ills of modernity; they represent backwaters where life assumes a less frantic pace and people are more sociable (Clark, 2004; King, 1993; McKechnie, 2002; Rainbird, 1999).

The common view of islands as isolated, bounded environments of limited size has influenced the development of research in the life sciences and anthropology to a 
considerable degree. The perception of the island as the ideal unit of scientific study arose, of course, in evolutionary biology. After all, it was on the Galápagos Islands that Charles Darwin encountered the numerous endemic faunal and floral life forms, notably the varying species of local finches, which gave rise to his theory of natural selection. While travelling in the Indonesian archipelago and the Philippines, the second founding father of evolutionary biology, Alfred R. Wallace, confirmed Darwin's understanding that the number and variety of the experiments shown by the endemic flora and fauna of especially oceanic islands provide unique insights into local evolutionary processes. Besides, he also formulated some of the major ideas of modern island biogeography, emphasizing that because of the reduced species diversity on islands they may be seen as natural laboratories where evolutionary processes are simpler and easier to disentangle than on mainlands.

The idea that small oceanic islands, like those of the Galápagos, would be equally excellent theatres to study the development of human culture crystallized towards the end of the $19^{\text {th }}$ century among social scientists, especially in Great Britain. Indeed, it formed a logical corollary to a line of thinking emphasized by the then ruling paradigm in anthropology, cultural evolutionism. Alfred C. Haddon was the first anthropologist to embrace this notion. He was trained as a zoologist before becoming an ethnographer, and was thus well acquainted with evolutionary biology. Haddon organized a multidisciplinary expedition to the Torres Strait in 1898, deeming it essential to study islands since their protected habitats would provide as natural a laboratory for human cultural variation as for the biological evolution of plants and animals (Gosden, 1999:49-50; Kohn, 2002; Kuklick, 1996).

In the early 1900s, Haddon was followed by a suite of mainly English anthropologists, including those who were to become the leading figures of the then developing school of functionalism, such as Alfred R. Radcliffe-Brown, who studied the inhabitants of the Andaman Islands, and Bronisław Malinowski, whose epoch-making fieldwork took place on Kiriwina in the Trobriand Islands of Melanesia. Their emphasizing of ethnographical study of populations living on small tropical islands enforced the general feeling among social scientists that such societies formed bounded, self-contained and easily manageable units, representing excellent objects for the structural-functionalist study of non-Western cultures. The island seemed to be a vessel in which all social life was contained. As explicitly formulated by Vayda \& Rappaport (1963), island societies being small-sized and isolated entities appeared to provide special opportunities for studying cultural development with a clarity lacking under mainland conditions. According to this viewpoint, which has been characterized as the "myth of the primitive isolate", island cultures can be considered isolated, closed aggregates lost in the backwaters of history (Eriksen, 1993; Rainbird, 1999; Terrell 1997; 1998; 2001; 2004; Terrell et al., 1997).

\section{Island Biogeography and Archaeology}

A fresh impetus to the myth of the primitive isolate was given by the development of quantitative island biogeography in the 1960s and 1970s, ultimately leading to the transfer from anthropology to archaeology of the idea of insular environments as circumscribed and isolated units of analysis. Island biogeography emphasizes that islands should be understood as bounded, isolated, fragile and variable habitats characterized by a high 


\section{A. Boomert \& A.J. Bright}

degree of floral and faunal endemism, in fact acting as natural laboratories simplifying the complexity of the natural world on mainlands. Remote island biotas differ from continental ones in various ways, being generally species-poor and disharmonic, yet rich in endemic species, thus contributing disproportionately to global diversity (Whittaker, 1998:2-4, 33).

Undoubtedly, the most influential contribution to island biogeographical theory has been Robert MacArthur \& Edward Wilson's The Theory of Island Biogeography, a book published in 1967 (following an article of 1963) which attempted to show how aspects of biogeographical variation could be modelled quantitatively using island environments. MacArthur \& Wilson supposed that a dynamic balance exists between island immigration of species and the extinction of local species. According to their dynamic equilibrium theory, the key variables determining this quantifiable balance of island biotas include distance to the mainland (influencing immigration) and island size (influencing extinction): small, distant islands would have relatively low immigration rates as well as lesser amounts of biodiversity and natural resources while large offshore islands would have higher immigration rates and support more species. This pattern could have been modified by geographical conditions such as the existence of stepping-stone islands: that is, chains of islands stretching out from a mainland. When the number of species migrating to an island matches the rate at which local species are going extinct, the equilibrium point is reached (Quammen, 1996:414; Whittaker, 1998:113-121). Though highly influential in its time, MacArthur \& Wilson's theory has proven remarkably difficult to test and at present is considered to be of limited predictive value (Whittaker, 1998:1, 118; 2004).

The central paradigm of insular biogeography is that islands, being clearly defined entities of varied geographical circumstances with tractable biotas, can be seen as simplified systems in which the effects of key factors can be isolated. This tenet proved highly attractive to social scientists. According to this view, islands provide a suite of natural settings from which the natural scientist can make selections that simplify the complexity of the natural world, enabling theories of general importance to be tested (Quammen, 1996:19). The concept of islands as laboratories for the study of cultural development was introduced to anthropology by Vayda \& Rappaport (1963) just before the publication of MacArthur \& Wilson's major work. They also adopted 'the founder principle' as a key genetic concept to explain human insular settlement. Vayda \& Rappaport's use of insular biogeography was soon noticed by archaeologists interested in assessing the potential of ecological and mathematical theories for explaining human dispersal, cultural variability and growth. After all, this was the heyday of processual archaeology when the influence of natural science on archaeological theorizing and methodological thinking was most profound. The island biogeographical model neatly dovetailed with the anthropological myth of the primitive isolate in emphasizing the physical circumscription and isolation of islands: that is, the reasons of their utility in understanding biological evolution (Vitousek, 2002). In a simplified version of the laboratory analogy, islands could be conceived of as little petri dishes floating in a saltwater medium (Held, 1989).

Evans $(1973 ; 1977)$ was the first to apply biogeographical principles to insular archaeology by introducing the idea of islands as laboratories for the study of cultural development. He opined that the sea divides and isolates communities, although it can be an effective 
communication medium when adequate water transport is available. Island societies would tend to be conservative and culturally traditional due to their relative physical isolation and protection from the competition of life on mainlands. Besides, they would at times be prone to exaggeratedly develop some cultural feature, often ceremonial or religious in character, such as the Malta temples and other Mediterranean monuments. Renfrew (1973:147-161) compared such "main island intensifications" with the erection of the platform statues of Rapa Nui (Easter Island) and other major building works in prehistoric Oceania. He felt that the very isolation of Easter Island led to this great florescence in statue building and that, similarly, isolation may have prompted the construction of monumental architecture on various Mediterranean islands (Renfrew, 1984; 2004).

Evans' and Renfrew's articles stimulated the application of island biogeographical approaches to the Mediterranean by other processual archaeologists. Cherry (1981; 1985; 1990) analyzed the first settlement of the Mediterranean islands, questioning whether insularity itself acted as a constraint on the manner and rate of their colonization by humans. While realizing that human island colonization suggests purposeful behaviour, he concluded, in accordance with MacArthur \& Wilson's stochastic formulae, that the order in which the Mediterranean islands were taken into use is to a certain extent a reflection of their size and distance from the mainland: large offshore islands were generally settled first followed at a later stage by smaller, more remote ones. In a similar vein, Terrell (1976; 1986:54-55) postulated a strong correlation between the number of languages spoken in the Solomon Islands and island size. Considering isolation "not a cause but a condition", he used proximal-point analysis to establish hypothetical network diagrams measuring isolation and communication. His research supposedly reveals the effect of distance on interaction, based as his diagrams are on the (unproven) assumption that people tend to interact most intensely with their nearest neighbours (Terrell, 1976; 1986:122-131).

Diamond (1977) and Diamond \& Keegan (1984) likewise focused on the application of biogeographical principles to the human discovery and settlement of islands: they adopted MacArthur and Wilson's distinction between pioneer, rapid-breeding, and fast dispersing ( $r$-selected) 'tramp' species and late successional, slow maturing, and limited dispersing $(K$-selected) 'sedentary' species. They characterized the Polynesians, Taino and Newfoundland Vikings as "supertramps", as in their view these peoples occupied only small or outlying islands, being barred by established human populations from mainlands and larger islands. In another study Keegan \& Diamond (1987) used MacArthur \& Wilson's biogeographical principles in an attempt to identify the general rules underlying human discovery and settlement of islands in order to determine significant patterns in the spatial distribution of insular cultures. Realizing that not all the world's near-shore islands were colonized before remote islands, or large islands before small ones, they identified a series of geographical variables ('effects') thought to influence human insular colonization, adding 'configurational' effects, notably the 'stepping-stone' and 'target' effects, to the central concepts of the dynamic equilibrium theory, that is, the distance and area effects.

The basic premise underlying all these studies - that there are deep similarities between the patterns of island distribution of human populations and those of other animal species, i.e. their respective forms of adaptive radiation - was widely shared. Kirch (1984:2-3; 1986a; 


\section{A. Boomert \& A.J. Bright}

1986b) stressed the discreteness and isolation of the Polynesian islands, accepting the idea that isolation accounted for much of the unicity of both their animal and human life. Believing these islands to represent ideal places for comparative experiments in adaptation and differentiation, he saw isolation as the most basic mechanism of cultural divergence in Oceania as it would have effectively reduced diffusion and cultural contact after island colonization. Kirch \& Green (1987) identified physical isolation as the key factor in rendering oceanic islands ideal theatres for phylogenetic studies. They attributed the interrelationship of Polynesian island societies more to descent from a postulated common ancestral tradition, i.e. Ancestral Polynesian Society, than to continuing interaction, in spite of their developed seafaring and navigational abilities, thus conceptualizing the region's cultural evolution as a process of adaptive radiation (Gosden \& Pavlides, 1994). Rouse (1986:118-125) reconstructed a comparable phylogeny of the Arawakan-speaking peoples of Amazonia to explain their movement into the Caribbean.

In addition, Kirch $(1984: 71,87,95)$ noted that the founder principle may have operated in Polynesia, as the prehistoric colonizing parties were small and therefore representative of only a portion of the cultural-behavioural variability in the mother population. The founder principle was similarly adopted by Rouse $(1986: 10,141)$ in order to explain the differentiation between the ceramics of the Cedrosan and Huecan subseries of the Saladoid series, produced by the first wave of horticultural migrants into the Caribbean. Furthermore, Watters (1982) and Watters \& Rouse (1989) called for a "seaward perspective" in the analysis of the Caribbean cultural adaptations, replacing the then dominant "landward orientation" in the interpretation of the region's prehistoric past.

Few island studies beyond the world's three major archipelagoes were influenced by insular biogeography. Yesner's analysis of the seasonal subsistence activities of the prehistoric maritime gatherers of the offshore islands and littoral zone of Maine forms an exception. Considering islands to be conveniently bounded units for the development of "middle-range" theory, he attempted to gauge the role biogeographical variation played in shaping the distribution of Maine's human populations (Yesner, 1988). Finally, in the Mediterranean, the approach initiated by Cherry was pursued by Held (1989) who developed a Target/Distance ratio in order to estimate mathematically the chance of insular discovery by humans. He concluded that only relatively accessible islands, with T/D ratios greater than 1.0, were colonized during the Pleistocene.

While accepting isolation as a major factor in Oceanic cultural evolution and employing biogeographical concepts such as the founder principle, Kirch (1984:19-20, 82, 1986a) stressed that insular boundedness should not be confused with closure, asserting that the idea of islands and island societies as closed systems, reflected in the frequent references to insular laboratories sensu Evans (e.g. Davis, 1988; Keegan \& Diamond, 1987; King, 1993; Terrell, 1976; 1977a; 1986:122; 1988), had been taken too far. Analyzing the biogeographical notion that oceanic islands form extremely fragile ecosystems with a tendency to great instability due to disturbance, Kirch (1984:20, 87-88, 123, 135-150; 1986a; 1997a:221-225; 1997b) synthesized the results of research into human degradation of Oceanic island habitats. He concluded that, apart from such activities as hunting, fishing, massive deforestation for agricultural purposes, house construction, and canoe 
building, the floral and faunal species deliberately or inadvertently introduced by humans were highly competitive and had a detrimental effect on the endemic, vulnerable wildlife of Pacific islands, particularly at lowland elevations. Equally dramatic examples of human impact on island habitats were first noted by Moore (1983) for St. Helena and Madagascar and by Morgan \& Woods (1986) for the Caribbean.

\section{The Postprocessual Reaction}

Dissatisfaction with the premises of island biogeography and its archaeological applications arose in the late 1980s. First of all, the insistence of the processualists on physical isolation as the key factor determining prehistoric development in island realms such as the Pacific and Mediterranean came under attack. Moreover, the predictions generated by MacArthur \& Wilson's biogeographical model repeatedly failed to match the actual situations of prehistoric insular discovery and settlement. Regarding the latter, for instance, Bowdler (1995) was unable to discover any relationship between the timing of occupation of Australia's offshore islands and factors such as their distance from the mainland, size, and configuration, or any combination of these 'effects' considered so significant by Keegan \& Diamond (1987). She resolved that human behaviour is not necessarily explicable in terms of models that take their lead from either common sense or the behaviour of other animal species. Similarly, Mitchell (2004) concluded that the date of initial colonization of Africa's principal islands appears to be related to their distance from the mainland; yet, its largest islands were by no means settled prior to its smallest ones. In fact, the huge insular sub-continent of Madagascar was first colonized at a relatively late date and mainly from Indonesia, not Africa. Finally, Bass (1998) had to conclude that the predictions of the model of biogeographical ranking and T/D ratios bore no resemblance to the actual discovery and settlement of the Adriatic Islands in the Mediterranean.

Patton (1996:1-4, 24, 34, 63, 180-182) pointed to the fact that the patterns of human insular exploration and colonization are essentially different from those of plants and animals, often being deliberate processes stemming from social and/or political motives and influenced by the levels of maritime technology and navigational knowledge at any given time. He also noted distinctions between humans and other animals as to food-getting practices and interaction patterns. In order to explore in more detail the effect of insularity on human populations, he felt that there was a need to develop "a theory of island sociogeography, focusing especially on the cultural dimensions of island life" (Patton, 1996:2526, 190). Nevertheless, Patton accepted the probability that the discovery of islands was influenced by biogeographical factors such as distance to the mainland, the existence of stepping-stone islands, and island size, though combined with cultural aspects such as the level of maritime technology and navigational ability.

The matter was most succinctly elucidated by Broodbank (2000:30-32), who noted that people and animals display great variability in their readiness to travel across water. Differences among animals are anatomy-dependent whereas among humans they result from variations in culture and technology, which may be culturally transitory. While people do indeed settle larger, closer islands first and most successfully, and while facilitating stepping-stone chains often speed things up, such patterns in human 


\section{A. Boomert \& A.J. Bright}

colonization tend to generate a great deal of 'noise', suggesting that geometrical properties seldom explain the whole story. Resemblances between the island-colonizing behaviour of highly proficient humans and animal supertramps do not teach us much. In Broodbank's opinion, island biogeography does not provide anything even close to a complete paradigm for understanding island societies. He concluded that an agenda for insular archaeology set out in terms of biogeographical issues of dispersal, adaptation, radiation, competition, and extinction is grossly over-reductive and will encourage "a minimalist vision of island life".

In addition to challenging biogeographical theory for modelling human discovery and colonization of islands, the implicit notion of the sea as the main factor isolating individual insular societies was seriously questioned. Gosden \& Pavlides (1994) pointed out that it was the sea that linked the Arawe Islands of Melanesia to the wider world, thus connecting rather than dividing. In their opinion, connectivity by sea rather than isolation is a more appropriate view of the role the ocean played in Pacific prehistory. They proposed the term "seascape" for island worlds: land of which the use is partially determined by the sea, allowing for the view that landscape and humans impact each other in equal measure. Broodbank (1993) suggested a similar perspective, concluding that the sea may be a boundary or a highway: he considered islands, and island clusters more so, as places that amplify and polarize isolation as well as interaction. In fact, Irwin, an archaeologist and accomplished yachtsman, had proposed this opinion more than a decade earlier, regarding the Pacific as a "sea of islands", acting like a bridge rather than a barrier (Irwin, 1980).

Anthropological research of island societies came to similar conclusions. Eriksen (1993) found that Mauritius was in continuous interaction with other insular and mainland societies, some very distant, resolving that contact with the outside world represents a universal feature of human societies. Rainbird (1999) attributed the idea that the islands of Oceania were isolated dots in a vast ocean to the typically Western perception of islands as strictly circumscribed, isolated entities. Fitzhugh \& Hunt (1997) argued that even the most remote islands of the Pacific were never isolates. Instead, the Polynesian islanders saw their world as a highway for travel and exploration, a great network or web of sea paths linking up the islands, a "sea of islands" (Hau'ofa, 1994; Rainbird, 2004:53; Terrell, 1988). In this respect, Rouse claimed over 50 years ago that prehistoric communities occupying parts of islands that faced each other across water gaps (passages) in the Greater Antilles appeared more closely related culturally than those on opposite ends of the same island. This suggested that interaction preferably took place by canoe, querying the assumption of unitary islands as ideal units of analysis (Rouse, 1951; 1986:128).

In keeping with the outward-looking view now credited to the islanders of the world, Broodbank (2000:21-22) proposed the concept "islandscape" as the best way of approaching island landscapes and seascapes, being an approach to insularity that incorporates the sea and maritime culture in its definition (Gosden \& Head, 1994). The emphasis on interaction rather than isolation and on idealist interpretations focusing on cultural meanings rather than deterministic biological and geographical models clearly reflects the influence of postprocessual archaeology, which manifested itself in the late 1980s and 1990s. Accordingly, islanding, i.e. the social operation of insularity, rather than islands became the focus of interest and islands were increasingly seen as social constructs 
("islands of mind") rather than as physical entities (Patton, 1996:33, 184). According to Eriksen (1993), the use of the island metaphor by the inhabitants of Mauritius, or by islanders in general, should be considered as illustrating the conscious manipulation of social and cultural boundaries deliberately aimed at the establishment of a Mauritian identity. Consequently, this strategic wielding of the insularity concept represents a creative way of establishing social identity.

\section{Discussion}

At present, biogeographical approaches to island environments have lost most of their appeal to archaeologists. Indeed, the pendulum has reversed its swing and Cherry (2004) even signals "a thorough distaste for any form of biogeographical reasoning" among researchers of insular settings, for some of whom "insularity is almost an inconvenience". Although his statement that "island biogeography remains a powerful theory whose relevance it is absurd to deny" needs qualification, particular aspects of biogeographical theory in general undoubtedly remain valid to the study of insular as well as mainland societies. For instance, the greater diversity of plant and animal species on large offshore islands when compared to smaller oceanic islands would have presented terrestrial-based prehistoric hunter-gatherers with better options for sustaining themselves. In this sense, biogeography may have impacted prehistoric humans' choice of settlement location and/or environmental exploitation to a considerable extent, as is shown by Fitzhugh et al. (2004) for the Kuril Islands between Japan and Kamchatka.

This is not to say that the unconditional and full application of the dynamic equilibrium theory to archaeological situations has been abandoned unjustifiably. Although its application yielded certain insights regarding human discovery and occupation of islands, the inherent negation of human motivation and meaning vested in insular exploration, voyaging, and settlement renders the theory unsuitable to a balanced understanding of the cultural processes in question. Certainly, as Newsom \& Wing (2004:26) argue, island biogeographical principles apply to human colonization of islands, as humans, like other organisms, have basic biological needs and islands have limited resources and clear constraints with which humans must cope. Indeed, the arrival of human settlers on islands obliges geographically circumscribed plant and animal endemic species into an intense interaction with these newcomers, as a result of which the latter generally effect a rapid extermination of the former. Also, small islands are extremely vulnerable when catastrophe strikes: their geographically limited biomass can be severely damaged and harvests completely destroyed by a single hurricane (Parker Pearson, 2004). While insular flora and fauna are indeed highly vulnerable as a result of their circumscribed environment, studies of human insular life that have appeared over the last 30 years have emphasized that humans, despite needing to overcome a number of hurdles such as developing advanced seafaring technology, are in the main impacted to a much lesser degree by geographical circumscription, because they developed cultural means to deal with such limitations or dangers, something that is beyond the capabilities of other animal species. In this respect, human (survival) strategies in island settings are not so dissimilar to those resorted to in engaging the natural world in mainland situations throughout the globe. 


\section{A. Boomert \& A.J. Bright}

Biogeography remains an important tool to gauge the extreme vulnerability of island ecosystems to the anthropogenic changes which characterized the Caribbean, Oceania, and other tropical archipelagoes during prehistory and afterwards (e.g. Burney, 1997). The massive erosion triggered through the clearing of hillsides dramatically altered the oceanic insular habitats, resulting in the development of grasslands or fernlands and the accumulation of vast loads of sediment in lowland areas (Jones \& Spriggs, 2002; Kirch, 1984:139-146; 2000:59-62, 313). This in itself elicited specific cultural responses, some of which, both in Polynesia and the Greater Antilles, eventually led to profound intensification of local horticulture (Newsom \& Wing, 2004:56-57, 200-204; Spriggs, 1997:85-86). The modification of the island ecosystems due to human-induced environmental degradation was enhanced by the deliberate introduction of (semi-) domesticated animals and the transporting of inadvertent stowaways, the "portmanteau biota", by the first horticultural settlers (Kirch, 1997a:218-220; White, 2004). The overexploitation of insular fauna and competition by introduced animals resulted in a dramatically depleted indigenous wildlife in the Caribbean, Oceania, and elsewhere.

The insight that the Caribbean and Oceanic insular environments and fauna were impacted dramatically by the prehistoric settlers of these archipelagoes has only been reached over the past twenty years or so. Previously, biogeographical researchers had assumed that the island ecosystems were not altered significantly by the indigenous Pacific and Caribbean populations. This erroneous assessment obviously had a major misdirecting impact on the formulation and testing of biogeographical theory, including MacArthur \& Wilson's stochastic principles of island immigration and extinction. Nevertheless, small islands are excellent places to study the solutions developed by human societies to cope with anthropogenic habitat perturbations such as those encountered on California's Channel Islands (Erlandson et al., 2004). Similarly, biogeographical reasoning continues to be important in reconstructing the rapid depletion of faunal resources in the Pacific and Caribbean during the first horticultural settlement. The initial targeting of high food value resources by the Lapita and Saladoid migrants, in line with an optimal foraging scenario, may have been an essential part of their colonization strategy, since their fast depletion formed a major impetus for new colonization events (Anderson, 2004; Keegan, 1995).

The postprocessual rejection of biogeography as a tool for modelling human insular behaviour has led to an overestimation of the degree and universality of prehistoric communication and interaction in the world's archipelagoes, trivialization of the act of voyaging, and the unwarranted negation of geographical and social isolation or remoteness of particular island communities. Of course, isolation is a highly relative concept. While complex networks of interconnections developed throughout the Pacific and Polynesians saw the sea as a highway connecting their communities, many island populations were indeed truly isolated for much of their prehistoric past, Easter Island, the Chathams, and Hawaii being the most outspoken examples. This was partly down to geographical factors, especially in Remote Oceania, but physical isolation appears to have been of less consequence than deliberate human decisions (Broodbank, 2000:32-33; Kirch, 2000:41, 57; Kirch \& Green, 1987, 2001:85-86). In the Pacific, powerful social barriers dictated the degree of communication or isolation between and within islands. The Maori at either end

of the main islands of New Zealand knew next to nothing about each other's lands while 
the Tasmanians and the inhabitants of the Bass Strait Islands simply ignored each other's communities for thousands of years (Anderson, 2004).

Clearly, access to islands depended on seafaring: their relative social/mental isolation or remoteness was determined by the relationship between the sea and craft. Technological advances in seafaring and navigation such as the invention of the sail in Oceania, the Mediterranean and the North Atlantic considerably enlarged the minimum passage distance possible and enabled an increase in the frequency of interaction among islands. Islands are typically inhabited by maritime-oriented people and boat-builders and/or owners are active and decisive agents in island life (Lape, 2004; Spriggs, 1997:27, 29). Polynesian mythology is full of tales of the great culture heroes who went in search of new lands. Access to boats, understanding of navigational principles, and knowledge of sailing magic, i.e. ritual necessary to survive the perils of long voyages, are often restricted to certain members of society, to whom it may serve as a means of manipulating power (Kirch, 1984:82; 2000:304; Patton, 1996:33). The voyaging conditions in Near Oceania resemble those of the Caribbean, which consists of one extended chain of stepping-stone islands. These archipelagoes offer intrinsically different possibilities for sea travel than Remote Oceania does (Irwin, 1992:21-23; Terrell et al., 1997).

The degree of interaction among islanders, therefore, is not only determined by physical factors but represents as much a cultural choice; that is, insularity is a concept created and manipulated strategically by the islanders themselves (e.g., Broodbank, 2000:20; Robb, 2001). Many islanders use the island metaphor to establish and express social identity. In the present world system island communities such as those of the Outer Hebrides have developed a strong sense of common identity against the outside world, which was reinforced by voyaging away from home. Such identities can engender in islanders the ideological strength needed to opt out or resist nation state incorporation (Parker Pearson, 2004). Island populations, whether real or perceived, maintain an attitude of remoteness from their more imposing neighbours in order to preserve a distinct ways of life: in essence their insularity. They have a powerful sense of self and insularity should be thought of as largely a cultural construct: islands as mainly ideas. It can now be appreciated that the decisions or customs of islanders and those of people in the outside world determined to a significant degree whether islands were predominantly bounded, closed systems or open ones, receptive to outside ideas (Broodbank, 2000:18-19, 33; Clarke, 2002).

The insularity metaphor is a convenient tool for social action. Loss of culture traits, deviation, and curation of archaisms were sometimes strategies through which island identities were created and sustained by people who knew how things were done elsewhere (Broodbank, 2000:20). The florescence in the construction of Maltese megalithic temples ca. $3600 \mathrm{BC}$ has been explained by following this line of reasoning, while previously Malta's insularity was invoked as explanation (Renfrew, 1973:147-161; 1984a; 1984b; 2004). Malta is a relatively isolated island, but in close connection with neighbouring large landmasses, predominantly Sicily. The Maltese islands were outliers of an extended exchange network, on the edge of the visible world (Malone \& Stoddart, 2004). Temple building is now seen as the result of both internal Maltese ritual development and a new strategy of identity, perhaps initiated by a ruling elite, which used the island metaphor to 


\section{A. Boomert \& A.J. Bright}

differentiate the Maltese from Sicilian 'others' with whom they were increasingly linked in exchange relationships. In this case, insularity would be a social construction resulting from less, not more, isolation. In effect, the Neolithic Maltese created a "cultural island", perhaps in reaction to social changes sweeping the region at the time (Robb, 2001).

As no island is truly isolated, single islands cannot be the ideal spatial units for analyzing insular societies. In contrast to MacArthur \& Wilson's island biogeographical dictum, the unitary island should be seen as just one point on a spectrum of potentially relevant frameworks ranging from a patch of coast to entire island groups, and beyond (Broodbank, 2000:1, 22, 33; J. Waldren, 2002; Yesner, 1988). Island populations often have frequent contacts with peoples on other islands or stretches of mainland, but not necessarily with those of their own island. Lape (2004) discusses the example of the precolonial inhabitants of the Banda Islands in East Indonesia who had regular close relationships with those on islands far away but hardly with settlers on their own island. Similarly, the local kinship groups of the Tlingit inhabiting the coastal zone and offshore islands of Southeast Alaska centred on the bodies of water that facilitated travel between the mainland and islands and among the islands. This created territories that in no way respected the physical boundaries of the individual islands of the region (Moss 2004). In early-contact period Trinidad the Yaio Amerindians of the southwest had little knowledge of the northeastern portion of the island and as late as the 1880s the inhabitants of Port-of-Spain in the northwest considered the Mayaro area of the southeast a strange country (Boomert, 2000:3). Finally, many islands of Melanesia are inhabited by maritime ("saltwater") and inland ("bush") populations who live in varying degrees of hostility with each other in spite of their mutual exchange of foodstuffs and commodities (Roe, 2000).

The participation of past or present island societies in regional, often archipelagic, spheres of interaction is or was essential to their functioning and survival. According to Broodbank (2000:110), in the early Cyclades the key to sustaining communities lay in the maintenance of inter-island networks and as such the regional analysis of zonal interaction should be a focus of analysis. It involves a grasp of the forces affecting maritime travel, the humanland interactions and the place of individual islands in the reticulate networks characterizing archipelagoes, i.e. seascapes of islands ("islandscapes"), created by the combination of sea and land (Broodbank, 2000:33). Most islands are tied into such reticulate networks. Study of their prehistoric past has frequently been characterized by opposing tendencies: either the ignoring of local traits and a focus on signs of external cultural influences and migrations or the emphasizing of autochthonous development. Both trends are encountered in the interpretation of e.g. the prehistory of Corsica (McKechnie, 2002). In contrast, the Isle of Man's past is normally seen as forming part of the contemporary development in the British Isles (Davey \& Innes, 2002), while the prehistory of the Balearic Islands is typically understood in local terms (W.H. Waldren, 2002). Clearly, instead of seeing each island as a distinct unit of study, a balance should be found between understanding its individual cultural development and that of its sphere of regional, often archipelagic, social interaction (Curet, 2004). Both fields of analysis are to be considered as mutually influencing since, as we have seen, distinctly single-island cultural manifestations often originated as a means of creating insular distinction and identity within the regional interaction sphere. The geographical scale and configuration of 
such a regional or archipelagic sphere are highly variable, ranging from islands extending from a mainland through distinct archipelagoes of varying extent and composition to unique outliers which can only be understood from an extreme macro-regional perspective.

A final matter needs to be addressed: are island societies essentially different from those of mainlands in comparable situations of communication and interaction with their neighbours? This, of course, is the major presupposition of island archaeology. In fact, it partially derives from island biogeographical thinking, according to which islands form natural laboratories simplifying the biotic complexity of mainlands allowing transparency of analysis and interpretation of the evolutionary processes involved (e.g. Royle, 2001:20, 41). Although at present even the staunchest supporters of the application of insular biogeographical approaches to archaeology have abandoned the once undisputed model of islands as laboratories for the study of cultural development (e.g. Cherry, 2004), the logical corollary that there are no structural dissimilarities in the patterned and cross-cultural human behaviour between island and mainland societies has not been drawn (e.g. Patton, 1996:33-34). Still, few examples disavowing this statement have been put forward. Indeed, the exaggerated development of island culture, often religious or ceremonial in character, expressed in some form of monumental architecture, has been attributed to insularity (Renfrew 1973, 1984a, 1984b), but, as noted by Rainbird (1999), worldwide monumental architecture is by no means an exclusive outcome of island living.

Almost 30 years ago, Terrell (1977b) concluded that there is no reason to think that the ecological and cultural processes acting upon island peoples are in any way different from those operating on continental populations. The same must then certainly apply to riverine and coastal groups. In fact, the common range of constraints impacting island societies does not vary from that affecting mainland communities in similar situations of communication and interaction. In this respect, Eriksen (1993) has noted that the most ancient Norwegian dialects are not spoken on the islands off the coast of Norway but in inland mountain valleys. They were preserved due to the distance of their speakers from the metropolis and their irregular contacts with it. Mountains tend to divide by hampering communication while water connects, as Rouse (1951) realized when reconstructing the prehistoric cultural development of the Greater Antilles. Similarly, during the prehistoric and early contact-period, southern Trinidad can be seen as essentially belonging to the South American coastal zone, connected with this area through a dense web of sea channels and rivers, whereas the interaction network in which North Trinidad partook comprised primarily Tobago and the southern Windwards (Boomert, 2000:3). Research in other parts of the Windward Islands has indicated equally strong interaction patterns across sea channels separating individual islands as across one island (Bright, 2005).

Taking one step further the arguing away of the presumed difference between human developments in mainland and island environments, one arrives at the conclusion that the only difference between terrestrial and maritime settings is the nature of the scape, which in turn affects the specific articulation and manifestation of human enterprise. In all environmental contexts, human settlement is clustered in discrete loci within a differentiated, activity-ridden land/seascape comprising both maritime and terrestrial domains. Phenomena such as human colonization, settlement, interaction, war, and 


\section{A. Boomert \& A.J. Bright}

exchange clearly transcend the local physical setting. Be that as it may, terrestrial activities have potentially left in situ traces visible to archaeologists, while activities that took place at sea in most cases have to be inferred indirectly from material remains on land as well, with the notable exception of sparse underwater archaeological finds. However, the fact that knowledge of human interaction with the sea will always remain somewhat less tangible than that of humans' activities on land need not stand in the way of an exchange of view. Essential to the approach suggested here is Cooney's (2003) recognition that, in archipelagoes and coastal areas, the sea is not just the main means of contact between inhabited places, it is central to the way of human life.

Rather than juxtaposing insular versus mainland communities, island and coastal societies in particular should be considered as structurally and ideologically closely related because of their focus on the sea, their lifestyles and beliefs being essentially moulded by their representing interacting human nodes in the seascape. It is the maritime cultural landscape (Westerdahl, 1992) shared by both littoral and insular communities that should form the research interest of archaeologists and anthropologists, encompassing both the material and immaterial aspects of human life on the continental seaboard and on islands. Local knowledge and lived experience are central to how people socialize seascapes. The sea achieved significance and became socially constructed in people's minds through active and enduring engagement. Consequently, coastal and insular people utilize and apprehend their maritime space in ways which depend on how they have traditionally experienced daily preoccupations with the sea and how, through ritualization processes, these concerns came to play a central role in their cosmological and religious beliefs (Cooney, 2003).

The sea, just as much as the land, can be a cultural creation since it is susceptible to similar cultural control: seascapes are knowable places (Rainbird, 2004:4). As Samson (2006) notes, people move on the sea in structured ways, and it is divided, populated and mythologized just like the land. Consequently, the archaeology of seascapes should involve material as well as spiritual engagements of human society with the sea (McNiven, 2003). Of course, the sea is universally recognized as a balance of opposites. Being ecological diverse and teeming with marine life, it provides a subsistence base in coastal and insular areas. However, the sea can also be treacherous and unpredictable: it gives and it takes, it can destroy and create land, it sustains life and it may kill. The sea is both valued and feared, to be utilized as well as respected (Cunliffe 2001:1, 7; Cooney, 2003). Our ambiguous perspective of the sea reflects the universal attitude towards water in general, which, being a fundamental source of human life, is endlessly transmutable, continually changing, and undergoing (often rhythmic) movement. Its motion is a potent metaphor for transition, voyaging, and progression (Richards, 1996; Strang, 2005).

The sea, then, represents an agent of transformation and travelling. In many societies the seashore is seen as a liminal zone, a boundary or margin where opposites meet, the place to offer sacrifices before undertaking a hazardous journey. Touching the sky at the far horizon, the sea forms a bridge between near and far, thus linking geographically distant places and peoples with celestially distant 'locales' and beings. Representing a "centre-outthere", the far horizon is one of the major power points of ritually activated conjunction between the cosmological realms of heaven, earth and underworld (Bradley, 2000:27; 
Helms, 1988:4, 25-26, 1993:194-195; Rainbird, 2004:5). In many societies the souls of the dead are believed to travel by boat across the sea to the western horizon in order to reach a mythical homeland or islands at this end of the world. Here, they can move up into the sky or downwards into subterranean regions. Ships are typically deployed metaphorically as vehicles for death and other states of transmission in social life such as initiation and marriage, for instance in Indonesia, Melanesia, and probably Bronze Age Scandinavia. In these areas long-distance travel across the sea and beliefs about death and the supernatural were closely intertwined, and these connections were manifested on both the local and regional levels (Ballard et al., 2003; Chapman \& Gearey, 2004; Helms, 1988:26-27, 217218; Kristiansen, 2004; Van de Noort, 2003).

As noted by Cunliffe $(2001: 554,565)$, the mindset of the inhabitants of the Western Atlantic seaboard and islands is dominated by the need to maintain an equilibrium with the fearsome natural force of the sea by competition and propitiation: the ocean is an adversary to challenge, but one demanding deep respect. The elements of the "oceanic mentality" he identifies, including challenge, awe, a heightened awareness of time, a deep restlessness, and a sense of limitless, are no doubt widespread among maritime communities across the world. Besides, from their adaptation to the sea for subsistence and long-distance exchange or raiding coastal dwellers and islanders globally have a joint outlook emphasizing periodic, often seasonal, absence from home by its male members, resulting in a structural emphasis on matrifocal family life as women must rely more on themselves and one another during the absence of their husbands. Marital bonds are weakened due to the men's cyclical sea travels and as a result in the long run maritime societies may come to emphasize matrilocality and even matrilineality (Keegan \& Maclachlan, 1989).

In sum, coastal and insular communities across the world, united as they are by their socializing, utilization and understanding of the sea, share a perspective and cultural forms which set them apart from societies of the continental interior. This finds its reflection in a dependence on maritime resources, the maintenance of seaborne social and political relationships, and spirituality and symbolism attached to water and the ocean. An archaeology of maritime identity must be able to operate at varying geographical scales, taking into account not only tangible, material remains, but also intangible cultural expressions, drawing upon trans-disciplinary research.

\section{Conclusions}

The primary postulate of island archaeology - namely that the manifestations of human behaviour on islands show persuasive structural similarities and are essentially divergent from those of mainlands - can be taken to be incorrect. Firstly, islands and archipelagoes are highly variable in a physical sense and the former uninterruptedly grade into mainlands. Secondly, island societies are impacted by a range of constraints quite comparable to those affecting mainland communities in similar situations of communication and interaction. An emphasis on boundedness and on physical and social/mental isolation of (small) island societies, which formerly dominated the literature, represents an outcome of the past predominance of biogeographical approaches in insular archaeology and anthropology. Certainly, the physical isolation and extreme ecological 


\section{A. Boomert \& A.J. Bright}

vulnerability of particularly insular flora and fauna to human predation cannot be denied. However, isolation can equally be a cultural construct employed by islanders to manipulate their own identity as opposed to that of their neighbours. Consequently, unitary islands are definitely not the ideal spatial units of archaeological or anthropological analysis. While archipelagoes, littoral areas, and inland territories do not offer entirely uniform conditions, human engagements with the world in different ecological settings show more similarities than environmental determinism would have us believe. Rather than seeking how to define the premises of a (sub)discipline called "island archaeology", thereby effectively isolating, thus islanding, ourselves academically, we must strive towards establishing an archaeology of maritime identity. Such an approach would encourage the study of human perspectives on and interaction, communication, and cultural development in archipelagic and coastal mainland, thus maritime, environments, where human societies are united by a focus on the sea, in an economic but also social, political and religious sense.

\section{Acknowledgements}

The authors are indebted to L. Antonio Curet, Jon M. Erlandson, Scott M. Fitzpatrick, Corinne L. Hofman, William F. Keegan, Alice V.M. Samson, Alexander Verpoorte, and anonymous reviewers for valuable comments on earlier drafts of this paper, which forms the outcome of research conducted under the auspices of the projects "Mobility and exchange: Dynamics of material, social and ideological relations in the pre-Columbian insular Caribbean" and "Socio-political complexity in the pre-Columbian Caribbean", funded by the Netherlands Organization for Scientific Research (NWO), and led by Prof. Corinne L. Hofman, Faculty of Archaeology, Leiden University, The Netherlands.

\section{References}

Anderson, A.J. (2004) 'Islands of Ambivalence' in S.M. Fitzpatrick (ed.) Voyages of Discovery: The Archaeology of Islands, Westport CT, Praeger, pp. 251-273.

Ballard, C., Bradley, R., Nordenborg Myhre, L. \& Wilson, M. (2003) 'The Ship as Symbol in the Prehistory of Scandinavia and Southeast Asia', World Archaeology, Vol. 35, No. 3, pp. 385-403.

Bass, B. (1998) 'Early Neolithic Offshore Accounts: Remote Islands, Maritime Exploitations, and the Trans-Adriatic Cultural Network', Journal of Mediterranean Archaeology, Vol. 11, No. 2, pp. 165-190.

Boomert, A. (2000) Trinidad, Tobago and the Lower Orinoco Interaction Sphere: An Archaeological/Ethnohistorical Study, Alkmaar, The Netherlands, Cairi Publications.

Bowdler, S. (1995) 'Offshore Islands and Maritime Explorations in Australian Prehistory', Antiquity, Vol. 69, pp. 945-958.

Bradley, R. (2000) An Archaeology of Natural Places, London, Routledge. 
Bright, A.J. (2005) Across the Channel: Southernmost Martinique and Northern St. Lucia Compared, paper presented at $21^{\text {st }}$ International Congress for Caribbean Archaeology, St. Augustine, Trinidad, University of the West Indies, July.

Broodbank, C. (1993) 'Ulysses Without Sails: Trade, Distance, Knowledge and Power in the Early Cyclades', World Archaeology, Vol. 24, No. 3, pp. 315-331.

Broodbank, C. (2000) An Island Archaeology of the Early Cyclades, Cambridge, Cambridge University Press.

Burney, D.A. (1997) 'Tropical Islands as Paleoecological Laboratories: Gauging the Consequences of Human Arrival', Human Ecology, Vol. 25, No. 3, pp. 437-457.

Chapman, H.P. \& Gearey, B.R. (2004) 'The Social Context of Seafaring in the Bronze Age Revisited', World Archaeology, Vol. 36, No. 4, pp. 452-458.

Cherry, J.F. (1981) 'Pattern and Process in the Earliest Colonization of the Mediterranean Islands', Proceedings of the Prehistoric Society, Vol. 47, pp. 41-68.

Cherry, J.F. (1985) 'Islands Out of the Stream: Isolation and Interaction in Early East Mediterranean Insular Prehistory' in A.B. Knapp \& T. Stech (eds.) Prehistoric Production and Exchange: The Aegean and Eastern Mediterranean, Los Angeles CA, Institute of Archaeology, Monograph 25, University of California, pp. 12-29.

Cherry, J.F. (1990) 'The First Colonization of the Mediterranean Islands: A Review of Recent Research', Journal of Mediterranean Archaeology, Vol. 3, No. 2, pp. 145-221.

Cherry, J.F. (2004) 'Mediterranean Island Prehistory: What's Different and What's New?' in S.M. Fitzpatrick (ed.) Voyages of Discovery: The Archaeology of Islands, Westport CT, Praeger, pp. 233-248.

Clark, E. (2004) 'The Ballad Dance of the Faeroese: Island Biocultural Geography in an Age of Globalisation', Tijdschrift voor Economische en Sociale Geografie, Vol. 95, No. 3, pp. 284-297.

Clarke, J. (2002) 'Insularity and Identity in Prehistoric Cyprus' in W.H. Waldren \& J.A. Ensenyat (eds.) World Islands in Prehistory: International Insular Investigations: V Deia International Prehistory Conference, Oxford, Archaeopress, BAR International Series 1095, pp. 537-544.

Cooney, G. (2003) 'Introduction: Seeing Land from the Sea', World Archaeology, Vol. 35, No. 3, pp. 323-328.

Cunliffe, B. (2001) Facing the Ocean: The Atlantic and its Peoples 8000 BC-AD 1500, Oxford, Oxford University Press. 


\section{A. Boomert \& A.J. Bright}

Curet, L.A. (2004) 'Island Archaeology and Units of Analysis in the Study of Ancient Caribbean Societies' in S.M. Fitzpatrick (ed.) Voyages of Discovery: The Archaeology of Islands, Westport CT, Praeger, pp. 187-201.

Davey, P.J. \& Innes, J.J. (2002) 'Innovation, Continuity and Insular Development in the Isle of Man' in W.H. Waldren \& J.A. Ensenyat (eds.) World Islands in Prehistory: International Insular Investigations: V Deia International Prehistory Conference, Oxford, Archaeopress, BAR International Series 1095, pp. 44-54.

Davis, D.D. (1988) 'Coastal Biogeography and Human Subsistence: Examples from the West Indies', Archaeology of Eastern North America, Vol. 16, pp. 177-185.

Diamond, J.M. (1977) 'Colonization Cycles in Man and Beast', World Archaeology, Vol. 8, No. 3, pp. 249-261.

Diamond, J.M. \& Keegan, W.F. (1984) 'Supertramps at Sea', Nature, Vol. 311, pp. 704705.

Eriksen, T.H. (1993) 'In Which Sense Do Cultural Islands Exist?', Social Anthropology, Vol. 1, No. 1B, pp. 133-147.

Erlandson, J.M. \& Fitzpatrick, S.M. (2006) 'Oceans, Islands, and Coasts: Current Perspectives on the Role of the Sea in Human Prehistory', Journal of Island and Coastal Archaeology, Vol. 1, No. 1, pp. 15-32.

Erlandson, J.M., Rick, T.C. \& Vellanoweth, R. (2004) 'Human Impacts on Ancient Environments: Case Study from California's Northern Channel Islands' in S.M. Fitzpatrick (ed.) Voyages of Discovery: The Archaeology of Islands, Westport CT, Praeger, pp. 51-83.

Evans, J.D. (1973) 'Islands as Laboratories for the Study of Culture Process' in C. Renfrew (ed.) The Explanation of Culture Change: Models in Prehistory, London, Duckworth, pp. 517-520.

Evans, J.D. (1977) 'Island Archaeology in the Mediterranean: Problems and Opportunities', World Archaeology, Vol. 9, No. 1, pp. 12-26.

Fitzhugh, B. \& Hunt, T.L. (1997) 'Introduction: Islands as Laboratories: Archaeological Research in Comparative Perspective', Human Ecology, Vol. 25, No. 3, pp. 379-383.

Fitzhugh, B., Moore, S., Lockwood, C. \& Boone, C. (2004) Archaeological Paleobiogeography in the Russian Far East: The Kuril Islands and Sakhalin in Comparative Perspective', Asian Perspectives, Vol. 43, No. 1, pp. 92-122.

Fitzpatrick, S.M. (2004a) 'Preface' in S.M. Fitzpatrick (ed.) Voyages of Discovery: The Archaeology of Islands, Westport CT, Praeger, pp. xiii-Xv. 
Fitzpatrick, S.M. (2004b) 'Synthesizing Island Archaeology' in S.M. Fitzpatrick (ed.) Voyages of Discovery: The Archaeology of Islands, Westport CT, Praeger, pp. 3-18.

Fitzpatrick, S.M. \& Erlandson, J.M. (2006) 'The Archaeology of Islands and Coastlines', Journal of Island and Coastal Archaeology, Vol. 1, No. 1, pp. 1-3.

Gosden, C. (1999) Anthropology and Archaeology: A Changing Relationship, London, Routledge.

Gosden, C. \& Head, L. (1994) 'Landscape - A Usefully Ambiguous Concept', Archaeology in Oceania, Vol. 29, pp. 113-116.

Gosden, C. \& Pavlides, C. (1994) 'Are Islands Insular? Landscape vs. Seascape in the Case of the Arawe Islands, Papua New Guinea', Archaeology in Oceania, Vol. 29, pp. 162-171.

Hau'ofa, E. (1994) 'Our Sea of Islands', The Contemporary Pacific: A Journal of Island Affairs, Vol. 6, No. 1, pp. 147-161.

Held, S.O. (1989) 'Colonization Cycles on Cyprus 1: The Biogeographic and Paleontological Foundations of Early Prehistoric Settlement', Report of the Department of Antiquities Cyprus, 1989, Nicosia, Ministry of Communications and Works, pp. 7-28.

Helms, M.W. (1988) Ulysses' Sail: An Ethnographic Odyssey of Power, Knowledge, and Geographical Distance, Princeton NJ, Princeton University Press.

Helms, M.W. (1993) Craft and the Kingly Ideal: Art, Trade, and Power, Austin TX, University of Texas.

Irwin, G.J. (1980) 'The Prehistory of Oceania: Colonization and Cultural Change' in A. Sherratt (ed.) The Cambridge Encyclopedia of Archaeology, Cambridge, Cambridge University Press, pp. 324-332.

Irwin, G.J. (1992) The Prehistoric Exploration and Colonization of the Pacific, Cambridge, Cambridge University Press.

Jones, R. \& Spriggs, M. (2002) 'Theatrum Oceani: Themes and Arguments Concerning the Prehistory of Australia and the Pacific' in B. Cunliffe, W. Davies \& C. Renfrew (eds.) Archaeology: The Widening Debate, Oxford, Oxford University Press, pp. 245-294.

Keegan, W.F. (1995) 'Modeling Dispersal in the Prehistoric West Indies', World Archaeology, Vol. 26, No. 3, pp. 400-420.

Keegan, W.F. \& Diamond, J.M. (1987) 'Colonization of Islands by Humans: A Biogeographical Perspective', Advances in Archaeological Method and Theory, Vol. 10, pp. 49-91. 
Keegan, W.F. \& Maclachlan, M.D. (1989) 'The Evolution of Avunculocal Chiefdoms: A Reconstruction of Taino Kinship and Politics', American Anthropologist, Vol. 91, No. 3, pp. 613-630.

King, R. (1993) 'The Geographical Fascination of Islands' in D.G. Lockhart, D. DrakakisSmith \& J. Schembri (eds.) The Development Process in Small Island States, London, Routledge, pp. 13-37.

Kirch, P.V. (1984) The Evolution of the Polynesian Chiefdoms, Cambridge, Cambridge University Press.

Kirch, P.V. (1986a) 'Introduction: The Archaeology of Island Societies' in P.V. Kirch (ed.) Island Societies: Archaeological Approaches to Evolution and Transformation, Cambridge, Cambridge University Press, pp. 1-5.

Kirch, P.V. (1986b) 'Exchange Systems and Inter-Island Contact in the Transformation of an Island Society: The Tikopia Case' in P.V. Kirch (ed.) Island Societies: Archaeological Approaches to Evolution and Transformation, Cambridge, Cambridge University Press, pp. 33-41.

Kirch, P.V. (1997a) The Lapita Peoples: Ancestors of the Oceanic World, Oxford, Blackwell.

Kirch, P.V. (1997b) 'Introduction: The Environmental History of Oceanic Islands' in P.V. Kirch \& T.L. Hunt (eds.) Historical Ecology in the Pacific Islands: Prehistoric Environmental and Landscape Change, New Haven CT, Yale University Press, pp. 1-21.

Kirch, P.V. (2000) On the Road of the Winds: An Archaeological History of the Pacific Islands Before European Contact, Berkeley CA, University of California Press.

Kirch, P.V. \& Green, R.C. (1987) 'History, Phylogeny, and Evolution in Polynesia', Current Anthropology, Vol. 28, No. 4, pp. 431-443; Comments \& Reply, pp. 443-456.

Kirch, P.V. \& Green, R.C. (2001) Hawaiki, Ancestral Polynesia: An Essay in Historical Anthropology, Cambridge, Cambridge University Press.

Kohn, T. (2002) 'Imagining Islands' in W.H. Waldren \& J.A. Ensenyat (eds.) World Islands in Prehistory: International Insular Investigations: $V$ Deia International Prehistory Conference, Oxford, Archaeopress, BAR International Series 1095, pp. 39-43.

Kristiansen, K. (2004) 'Sea Faring Voyages and Rock Art Ships' in P. Clark (ed.) The Dover Bronze Age Boat in Context: Society and Water Transport in Prehistoric Europe, Oxford, Oxbow Books, pp. 111-121. 
Kuklick, H. (1996) 'Islands in the Pacific: Darwinian Biogeography and British Anthropology’, American Ethnologist, Vol. 23, No. 3, pp. 611-638.

Lape, P.V. (2004) 'Isolation Metaphor in Island Archaeology' in S.M. Fitzpatrick (ed.) Voyages of Discovery: The Archaeology of Islands, Westport CT, Praeger, pp. 223-232.

MacArthur, R.H. \& Wilson, E.O. (1963) 'An Equilibrium Theory of Insular Zoogeography', Evolution, Vol. 17, pp. 373-387

MacArthur, R.H. \& Wilson, E.O. (1967) The Theory of Island Biogeography, Princeton NJ, Princeton University Press.

Malone, C. \& Stoddart, S. (2004) 'Towards an Island of Mind?' in J.F. Cherry, C. Scarre \& S. Shennan (eds.) Explaining Social Change: Studies in Honour of Colin Renfrew, Cambridge, McDonald Institute, pp. 93-102.

McKechnie, R. (2002) 'Islands of Indifference' in W.H. Waldren \& J.A. Ensenyat (eds.) World Islands in Prehistory: International Insular Investigations: $V$ Deia International Prehistory Conference, Oxford, Archaeopress, BAR International Series 1095, pp. 127134.

McNiven, I.J. (2003) 'Saltwater People: Spiritscapes, Maritime Rituals and the Archaeology of Australian Indigenous Seascapes', World Archaeology, Vol. 35, No. 3, pp. 329-349.

Mitchell, P. (2004) 'Towards a Comparative Archaeology of Africa's Islands', Journal of African Archaeology, Vol. 2, No. 2, pp. 229-250.

Moore, D.M. (1983) 'Human Impact on Island Vegetation' in W. Holzner, M.J.A. Werger \& I. Ikusima (eds.) Man’s Impact on Vegetation, The Hague, Junk, pp. 237-246.

Morgan, G.S. \& Woods, C.A. (1986) 'Extinction and the Zoogeography of West Indian Land Mammals', Biological Journal of the Linnean Society, Vol. 28, pp. 167-203.

Moss, M.L. (2004) 'Island Societies Are Not Always Insular: Tlingit Territories in the Alexander Archipelago and the Adjacent Alaska Mainland' in S.M. Fitzpatrick (ed.) Voyages of Discovery: The Archaeology of Islands, Westport CT, Praeger, pp. 165-83.

Newsom, L.A. \& Wing, E.S. (2004) On Land and Sea: Native American Uses of Biological Resources in the West Indies, Tuscaloosa AL, University of Alabama Press.

Parker Pearson, M. (2004) 'Island Prehistories: A View of Orkney from South Uist' in J.F. Cherry, C. Scarre \& S. Shennan (eds.) Explaining Social Change: Studies in Honour of Colin Renfrew, Cambridge, McDonald Institute, pp. 127-140. 


\section{A. Boomert \& A.J. Bright}

Patton, M. (1996) Islands in Time: Island Sociogeography and Mediterranean Prehistory, London, Routledge.

Quammen, D. (1996) The Song of the Dodo: Island Biogeography in an Age of Extinction, New York NY, Scribner.

Rainbird, P. (1999) 'Islands out of Time: Towards a Critique of Island Archaeology', Journal of Mediterranean Archaeology, Vol. 12, No. 2, pp. 216-234; Comments, pp. 234258; Reply, pp. 259-260.

Rainbird, P. (2004) The Archaeology of Micronesia, Cambridge, Cambridge University Press.

Renfrew, C. (1973) Before Civilization: The Radiocarbon Revolution and Prehistoric Europe, London, Jonathan Cape.

Renfrew, C. (1984) Approaches to Social Archaeology, Edinburgh, University of Edinburgh Press.

Renfrew, C. (2004) 'Islands Out of Time? Towards an Analytical Framework' in S.M. Fitzpatrick (ed.) Voyages of Discovery: The Archaeology of Islands, Westport CT, Praeger, pp. 275-294.

Richards, C. (1996) 'Henges and Water: Towards an Elemental Understanding of Monumentality and Landscape in Late Neolithic Britain', Journal of Material Culture, Vol. 1, No. 3, pp. 313-336.

Robb, J. (2001) 'Island Identities: Ritual, Travel and the Creation of Difference in Neolithic Malta', European Journal of Archaeology, Vol. 4, No. 2, pp. 175-202.

Roe, D. (2000) 'Maritime, Coastal and Inland Societies in Island Melanesia: The BushSaltwater Divide in Solomon Islands and Vanuatu' in S. O'Connor \& P. Veth (eds.) East of Wallace's Line: Studies of Past and Present Maritime Cultures of the Indo-Pacific Region, Rotterdam, A.A. Balkema, pp. 197-222.

Rouse, B.I. (1951) 'Areas and Periods of Culture in the Greater Antilles', Southwestern Journal of Anthropology, Vol. 7, pp. 248-265.

Rouse, B.I. (1986) Migrations in Prehistory: Inferring Population Movement from Cultural Remains, New Haven CT, Yale University Press.

Royle, S.A. (2001) A Geography of Islands: Small Island Insularity, London, Routledge.

Samson, A. (2006) 'Offshore Finds from the Bronze Age in North-Western Europe: The Shipwreck Scenario revisited', Oxford Journal of Archaeology, Vol. 25, No. 4, pp. 371388. 
Spriggs, M. (1997) The Island Melanesians, Oxford, Blackwell.

Strang, V. (2005) 'Common Senses: Water, Sensory Experience and the Generation of Meaning', Journal of Material Culture, Vol. 10, No. 1, pp. 92-120.

Terrell, J.E. (1976) 'Island Biogeography and Man in Melanesia', Archaeology and Physical Anthropology in Oceania, Vol. 11, No. 1, pp. 1-17.

Terrell, J.E. (1977a) ‘Biology, Biogeography and Man', World Archaeology, Vol. 8, No. 3, pp. 237-248.

Terrell, J.E. (1977b) 'Geographic Systems and Human Diversity in the North Solomons', World Archaeology, Vol. 9, No. 1, pp. 62-81.

Terrell, J.E. (1986) Prehistory in the Pacific Islands: A Study of Variation in Language, Customs and Human Biology, Cambridge, Cambridge University Press.

Terrell, J.E. (1988) 'History as a Family Tree, History as an Entangled Bank: Constructing Images and Interpretations of Prehistory in the South Pacific', Antiquity, Vol. 62, No. 237, pp. 642-657.

Terrell, J.E. (1997) 'The Postponed Agenda: Archaeology and Human Biogeography in the Twenty-First Century', Human Ecology, Vol. 25, No. 3, pp. 419-436.

Terrell, J.E. (1998) ‘The Prehistoric Pacific’, Archaeology, Vol. 51, No. 6, pp. 56-63.

Terrell, J.E. (2001) 'The Uncommon Sense of Race, Language, and Culture' in J.E. Terrell (ed.) Archaeology, Language, and History: Essays on Culture and Ethnicity, Westport CT, Bergin \& Garvey, pp. 11-30.

Terrell, J.E. (2004) 'Island Models of Reticulate Evolution: The "Ancient Lagoons" Hypothesis' in S.M. Fitzpatrick (ed.) Voyages of Discovery: The Archaeology of Islands, Westport CT, Praeger, pp. 203-222.

Terrell, J.E., Hunt, T.L. \& Gosden, C. (1997) 'The Dimensions of Social Life in the Pacific: Human Diversity and the Myth of the Primitive Isolate', Current Anthropology, Vol. 38, No. 2, pp. 155-175; Comments, pp. 175-184; Reply, pp. 184-195.

Van de Noort, R. (2003) 'An Ancient Seascape: The Social Context of Seafaring in the Early Bronze Age', World Archaeology, Vol. 35, No. 3, pp. 404-415.

Vayda, A.P. \& Rappaport, R.A. (1963) 'Island Cultures' in F.R. Fosberg (ed.) Man's Place in the Island Ecosystem: A Symposium, Hawaii HI, Bishop Museum Press, pp. 133-142. 


\section{A. Boomert \& A.J. Bright}

Vitousek, P.M. (2002) 'Oceanic Islands as Model Systems for Ecological Studies', Journal of Biogeography, Vol. 29, pp. 573-582.

Waldren, J.D. (2002) 'Conceptions of the Mediterranean: Islands of the Mind' in W.H. Waldren \& J.A. Ensenyat (eds.) World Islands in Prehistory: International Insular Investigations: V Deia International Prehistory Conference, Oxford, Archaeopress, BAR International Series 1095, pp. 1-6.

Waldren, W.H. (2002) 'Links in the Chain: Evidence of Sustained Prehistoric Contact and Cultural Interaction between the Balearic Islands and Continental Europe' in W.H. Waldren \& J.A. Ensenyat (eds.) World Islands in Prehistory: International Insular Investigations, V Deia International Prehistory Conference, Oxford, Archaeopress, BAR International Series 1095, pp. 152-185.

Waldren, W.H., Waldren, J.D., Ensenyat Alcover, J., Ensenyat i Julia, J., Reumer, J., Van Strydonck, M., Davis, S., Moorbath, S., Durst, C., Gardner Shelby, B., Gardner Shelby, A., Weaver, H., Weaver, P. \& Nemecek Peterson, M. (2002) 'Preface' in W.H. Waldren \& J.A. Ensenyat (eds.) World Islands in Prehistory: International Insular Investigations: $V$ Deia International Prehistory Conference, Oxford, Archaeopress, BAR International Series 1095, p. xi.

Watters, D.R. (1982) 'Relating Oceanography to Antillean Archaeology: Implications from Oceania', Journal of New World Archaeology, Vol. 5, No. 2, pp. 3-12.

Watters, D.R. \& Rouse, B.I. (1989) 'Environmental Diversity and Maritime Adaptations in the Caribbean Area' in P.E. Siegel (ed.) Early Ceramic Population Lifeways and Adaptive Strategies in the Caribbean, Oxford, BAR International Series 506, pp. 129-144.

Westerdahl, C. (1992) 'The Maritime Cultural Landscape', The International Journal of Nautical Archaeology, Vol. 21, No. 1, pp. 5-14.

White, J.P. (2004) 'Where the Wild Things Are: Prehistoric Animal Translocation in the Circum New Guinea Archipelago' in S.M. Fitzpatrick (ed.) Voyages of Discovery: The Archaeology of Islands, Westport CT, Praeger, pp. 47-164.

Whittaker, R.J. (1998) Island Biogeography: Ecology, Evolution, and Conservation, Oxford, Oxford University Press.

Whittaker, R.J. (2004) 'The Importance of Islands' in M.V. Lomolino, D.F. Sax \& J.H. Brown (eds.) Foundations of Biogeography: Classic Papers with Commentaries, Chicago IL, University of Chicago Press, pp. 931-941.

Yesner, D.R. (1988) 'Island Biogeography and Prehistoric Human Adaptation on the Southern Coast of Maine (USA)' in G. Bailey \& J. Parkington (eds.) The Archaeology of Prehistoric Coastlines, Cambridge, Cambridge University Press, pp. 53-63. 